\title{
Teaching Professional Language at University Level
}

\author{
M. Vozna \\ Taras Shevchenko National University of Kyiv, Ukraine \\ Corresponding author. E-mail: voznamarina2129@gmail.com \\ Paper received 13.01.20; Accepted for publication 28.01.20.
}

\begin{abstract}
https://doi.org/10.31174/SEND-Ph2020-216VIII64-14
\end{abstract}
Abstract. The article looks into the history of teaching English for Special Purposes in the West and in Ukraine and the related issue of the current understanding of the term 'professional language', otherwise known as English for Special Purposes. The study is an attempt to determine the place of the academic discipline called 'Professional Language' taught to linguistic and non-linguistic students of English in Ukraine, who are non-native speakers, its purpose and objectives, as well as the principles used to select teaching materials for the discipline. The article tries to differentiate this particular discipline from Terminology and English for Academic Purposes by specifying the subject matter of these neighboring disciplines and the teaching focus given in each particular case.

Keywords: English for Special Purposes, professional language, terminology, teaching materials, professional communication.

Introduction. The rapid development of science and technology, resulting in the widening of professional communication between representatives of different nations and cultures in the $20^{\text {th }}$ century and, especially, at the beginning of the $21^{\text {st }}$ century, determined the necessity of a stricter definition of the term 'professional language', contrasting it to terminology.

This involved multi-faceted research of 'professional language' in different fields of human knowledge and activity, which itself brought on the development of general methodological principles and specific methods of teaching this kind of language to different interested parties. Teaching professional English used in different academic disciplines and areas of professional communication to non-native speakers majoring in these areas, who use it as means of professional communication, has a long tradition both in the West and in Ukraine. Thus, we are talking about teaching professional English to nonlinguistic university students, such as future lawyers, economists, physicists and so on. A recent outcome in such tuition is the necessary focus on teaching the same discipline to linguistic students. In particular, future translators, who by the nature of their profession, will be engaged in studying, developing, and teaching professional language, as well as translating from one language into another. This facilitates professional communication and the sharing of specialised knowledge throughout the world. Following this trend, syllabi of some linguistics and translation departments at Ukrainian universities include the discipline of Professional English as such, or with the definition of the area of use, for instance Legal English, English for Economists, English in Banking and Finance, Courtroom English, Journalistic English etc.

So, what kind of Professional English should be taught to future linguists and translators, given the fact that their knowledge in the abovenamed areas is limited and, by definition, is less than that of the students majoring in these areas? What style should we focus on: purely academic, popular science, informal professional communication, or professional colloquial speech? And, if the discipline of Professional English is named broadly, what specific subject areas should be chosen? What is the correlation of Professional English and Terminology and English for Academic Purposes? And what purpose and objectives should be sought when teaching Professional English to linguistics and translation students?
This article strives to give a short overview of the basic notions of the discipline and its history abroad and in Ukraine and to describe tentative approaches to teaching this discipline to future linguists and, specifically, translators, the majority of whom without any doubt will deal with professional and special language in their future careers.

Short review of publications. In English-language linguistics professional language has mostly been called English for Special/Specialised Purposes (ESP), but some other names have also been used, such as technical English, scientific English, Professional English, Academic English and others [1, p.262]. Such diversity in names, on one hand, reflects the evolution of this notion from purely academic and technical written texts to a broader understanding of this term that includes oral communication with its specific genres, grammar and vocabulary and, on the other hand, demonstrates that there is no single commonly-accepted understanding of the notion.

It is worth mentioning that the interest in professional language in English and American linguistics arose from purely practical needs of teaching English to professionals, who are non-native speakers, first of all, in such areas as management studies and economics. The evolution of teaching English for Special Purposes has undergone at least four stages, starting from the 1960s. A short overview of this evolution is needed to understand the didactic aspect of English for Special Purposes, which helps to determine the methodology and practical approaches to teaching this discipline at the present time.

At the first stage, the focus was laid on lexical and grammatical characteristics of sentences in written texts of certain areas, for instance, business or commerce. At the second stage, during the 1970-80s, the focus shifted to rhetoric functions, where students were encouraged to analyze the objectives that the author of the text wanted to attain by using certain grammatical constructions. From the middle of the 1980s the focus shifted further to communicative intentions of the participants in the speech act mainly in oral professional communication. At this, third stage, textbooks of English for Special Purposes underwent significant change. Whereas at the first and second stages they were structured by grammar categories, for instance, the use of active and passive voice, or rhetorical functions found in written discourse, for instance, an introduction to an academic article or a letter containing a 
business proposal. This third stage took the communicative intention or function of the speaker, such as expressing gratitude or compliments, as the basis for structuring textbooks. Such textbooks contain examples of oral communicative situations in various professional areas where such intention or function was successfully achieved. The fourth stage of the evolution started at the end of the 1980s, with the widely acclaimed work by T. Hutchinson and A. Waters [2], which built on the achievements in psycholinguistics and raised the issue of the necessity to analyse student needs and their level of English when creating teaching materials and building the tuition process. Other factors to be taken into account include students' interest in the factual materials that are used in tuition, and their active involvement in composing syllabi, all of which together significantly raises their motivation to learn.

Research results. These new psycholinguistic approaches gave birth to a new trend in teaching English for Special Purposes, which was given the name of Content and Language Integrated Learning. This approach is used to teach specialist, non-linguistic subjects to those students for whom English is a second non-native language. This approach is practiced in Ukraine, specifically in Taras Shevchenko National University of Kyiv, where lecturers of non-linguistic subjects teach their specialist subjects in English. In this respect it should be noted that the described approach is poorly suited to teaching professional English at linguistic departments of universities where lecturers of the discipline are linguists and do not possess specialist knowledge of the subject area, even nearly to the same degree as specialists in the same area. At the same time for obvious reasons, specialist lecturers who are non-linguists, but have a good command of the language, are first and foremost interested in the contents aspects of their specialist discipline and are not at all focused on teaching English as such, as English for them is only a tuition tool, and not its purpose.

Teaching English for Special Purposes at linguistic departments is quite a new phenomenon in the Ukrainian university environment, whereas teaching the same discipline at non-linguistic departments has had a long tradition in both Ukraine and abroad, where ESP is taught at non-linguistic departments by linguists who specialize in teaching this discipline at a particular non-linguistic department. Their methods are closer to teaching the same discipline to linguistic students, with the difference that they know the subject area of the specific department where they work much better, and thus have advantages when choosing language material for tuition purposes from the point of view of its up-to-date content, the typical genres, and styles of communication in a particular professional environment.

It is not surprising then that at the beginning of the $21^{\text {st }}$ century linguists shifted their focus from the didactic aspects of professional language, i.e. how to teach, to a clear understanding of what this professional language should look like, i.e. what to teach. Here two major trends should be taken into account, common to any professional environment: those of globalization and specialization. This means that only such language material should be selected which reflects the current state of a particular area of knowledge and is, therefore, of professional inter- est for non-linguistic students.

In this respect, Anthony Laurence's view on the current state of Teaching English for Special Purposes by should be highlighted: 'While many General English teachers can be described as using an ESP approach, basing their syllabi on a learner needs analysis and their own specialist knowledge of using English for real communication, it is the majority of so-called ESP teachers that are using an approach furthest from that described above. Instead of conducting interviews with specialists in the field, analysing the language that is required in the profession, or even conducting students' needs analysis, many ESP teachers have become slaves of the published textbooks available, unable to evaluate their suitability based on personal experience, and unwilling to do the necessary analysis of difficult specialist texts to verify their contents' [3]. Thus, a conclusion should be made about the necessity of permanent, close contact between English teachers and experts in certain areas of knowledge aiming at the correct choice of language material used for tuition, that would be up to date both in content and terminology and typical for particular genres and styles of specific professions.

The definition of the term 'professional language', which is crucial for the correct choice of teaching materials, needs to take into account, in the first instance, that Ukrainian linguistics does not use corresponding English terms but the calque of the German linguistic term 'Fachsprache', which became widely spread in the 1960-70s with the meaning of 'the language of a certain area, profession'. The most quoted and commonly used understanding of the above term, both in Ukrainian and world linguistics, belongs to the German linguist Hoffmann, who defines professional language as 'the combination of all language means that are used in a specifically defined communicative area to achieve understanding among professionals in this area' [4, p. 53]. This definition is then extended by Taras Kiyak, a renowned Ukrainian linguist in the area of terminology, who stresses the importance of terminological systems for professional language and specifically says that 'the existence of professional language is ensured exclusively by strictly defined terminology' [5, p.28]. This point is proved by the history of academic research of professional language, which at earlier stages concerned itself exclusively with professional vocabulary and later saw terminology splintering off as a separate discipline. Herein lies the importance of the notions - 'the term' and 'terminology' - for further research into professional language and teaching the subject, as it is quite obvious that future linguists and future translators, in particular, must have a clear understanding of the nature of the term, its functioning, and methods of its formation. Therefore, it would be useful for students to know the classification of the vocabulary of professional text given by Taras Kiyak, who divided it into four types:

- Terms of a particular area that have their own definition.

- General academic terminology used in many areas, including terms of neighbouring areas.

- Half-terms or professional words, including nomenclatures.

- Professional colloquial words, which do not claim to be accurate or unambiguous, but at the same time 
are figurative and emotionally coloured [5, p.29].

Identification of the different types of terminology and other such vocabulary in specialised texts should be considered when choosing teaching material for the discipline and writing associated tasks and exercises. The tasks of identifying terminology and classifying lexis in special texts are aimed at helping students to analyze differences between special texts of various genres and disciplines from the terminological viewpoint, to differentiate between purely academic texts, applied science and technology texts, and popular science texts. Topical issues for teaching the discipline should include analysis of the processes of penetration of terminology of certain areas into the general use lexical stratum and vice versa, which must be studied in the broader context of correlation between professional language and general language. This broader, analytical approach is what, in our point of view, differentiates the discipline of terminology from ESP. The latter provides us with a broader, more complex approach to analyse terminology abundant texts, as well as tools to follow the processes, when terms, so to speak, leave the boundaries of their terminological systems.

No less important for students is the analysis of a special text as a whole language unit and its grammar specifics at the sentence level, namely, syntactical structures, cohesion words, text structure on the whole, subdivision into paragraphs, titles, etc. Students should be taught to differentiate between degrees of abstractness of a special text and functional styles, to which such texts belong. Identification of texts as such that belong to purely academic style (language of theoretical science) and professional practice style (formal professional communication, business jargon), which are singled out by certain linguists [5, p.31], would be useful for students. Thus, texts representing such styles and substyles must be selected for teaching materials. One cannot but agree with the reasoning behind the necessity of studying texts of different genres and styles and the specifics of their translation that are given by O.Yaschuk and O. Tsepkalo: 'Future professional, given the realities of contemporary life, should not only have profound knowledge in their area of expertise, but also have all possible language resources for sharing and spreading this knowledge at various professional conferences, symposia, during business trips; be able to deal with technical documentation and translate it, if necessary, obtain and use information in different languages depending on the communicative situation' [6, p.369]. And although this quotation was written about non-linguistic students, the same skills and knowledge should become part of the professional competence of a translator, for instance, who is involved in various forms and situations of professional communication as a translator.

The contents of professional language as a discipline for linguistic students should differ nit only from terminology, but also from English for Academic Purposes (EAP), which became part of our curricula in the recent years. Teaching EAP abroad for non-native speakers focuses first of all on the grammar of academic texts and the stratum of general academic vocabulary that is not specific to any particular area of knowledge. Specialised professional texts are given only as examples in lexical and grammatical exercises. Terminological systems of particular areas as such, are not studied. The discipline focuses mostly on purely academic texts with a high degree of abstraction and some genres such as academic articles, presentations at a conference, presentations of your MA or PhD theses and some others. Such an approach springs from the practical needs of teaching EAP to academics who represent different cultures and work in different professional fields. The experience of teaching this discipline to linguistics students at Taras Shevchenko National University of Kyiv proved the necessity of combining the above described world tendencies in teaching EAP with the teaching of the specifics of professional communication of such students in their professional field, specifically linguistics and translation studies. That which centres on the introduction of the corresponding texts into the teaching materials for EAP. The issues to be studied in detail include: the differences in the existing terminological systems of linguistics and translatology in Ukrainian and English, including 'false translators' friends', grammar mistakes typical for Ukrainian students, and comparing and contrasting the stylistic specifics of academic speech in English and Ukrainian.

Future linguists and translators should also be taught to pay close attention to the cultural and language environment, in which communication takes place. There are areas of knowledge where terminological systems achieve a high degree of homogeneity, such as, for instance, medicine and natural science, as the notions which they signify in different languages are either identical or very similar. Thus, most terms in such terminological systems have their unequivocal equivalents. There are, on the other hand, such areas of knowledge, such as, for instance, law and philosophy, where the semantic volumes of notions either do not coincide at all or coincide only partially. In such areas, translators will not be able to rely on dictionaries in many instances, but on the context. Thus, as it was correctly put by T. Halushko, the translator should be taught to 'take into consideration the degree of homogeneity of a particular professional field when working on the semantic content of their translation' [7, p.49].

The above considerations support the legitimacy of the division of the discipline 'Professional Language' for students of linguistic departments into at least two subjects based on the accepted in linguistics 'horizontal' classification of professional language: 'Professional Language of the Arts' and 'Professional Language of Natural Science', which differ between themselves by the degree of homogeneity of the language they use (the latter being more homogenic) - different lists of genres in oral and written professional communication. Recently the tendency can also be observed at the linguistics departments of teaching professional language of certain specific fields and its translation, for instance, the professional language of economics and finance, applied science and technology, cinema screenplay translation, medical translation, legal translation, courtroom translation and others. It is obvious even from this list that it is impossible to cover all subject areas as they are too numerous, and each subject area can also be further be divided into sub-areas and specialisations. Thus, teaching professional language to future linguists should cover broader areas of knowledge, the language of which has common typical features and relies on inter-branch and general academic 
terminological systems. For instance, the subject 'Professional Language of the Arts' may include the sublanguage of philosophy, sociology, psychology, mass communication, political science, history, linguistics, pedagogy, ecology, etc.

Conclusion. Teaching 'Professional Language' at linguistic and translation departments should be aimed at, firstly, familiarising students with the specifics of oral and written professional communication, represented by typical genres and texts of broad neighbouring areas of knowledge, and, secondly, with their terminological systems, focusing on general academic and inter-branch terms. The objectives of the tuition of future linguists and translators may include the formation of linguistic and translation skills and competences that would allow students to:

- $\quad$ to analyse special texts from the point of view of their genre and style, homogeneity of their terminological systems in different languages, the degree of abstractness, and logical construction.

- $\quad$ to analyse a communicative situation from the point of view of the intentions and language competence of its participants, its formal or non-formal nature and other factors.

- to know the principal methods of how new terms are formed and translated.

- be able to recognize instances when terms migrate from professional domains to general language and vice versa.

- $\quad$ to master a specific limited volume of professional terminology with the focus on general academic and inter-branch terminology.

Furthermore, teaching 'Professional Language' to future linguists should be split into at least two subjects: 'Professional Language of the Arts' and 'Professional Language of Natural Science', and when feasible and as mandated by the practical needs of a university, into sublanguages of separate disciplines. Professional language as a discipline should be separate from English for Academic Purposes and Terminology. Language material for the discipline should be selected from authentic sources with the advice of experts in particular areas on how representative texts are of a particular area, how up-to-date their content and their terminology are, and what the most typical communicative situations in their area are. Language material should include the most typical genres and styles, including purely academic and popular science, and examples of both oral and written professional communication.

\section{REFERENCES}

1. Nagy, Imola Katalin. English for Special Purposes: Specialized Languages and Problems of Terminology// Acta Universitatis Sapientiae, Philologica, 6, 2 (2014). - P. 261-273.

2. Hutchinson, T. Waters, A.1987. Developments in ESP. A Multidisciplinary Approach. - Cambridge: Cambridge University Press. -183 pp.

3. Laurence, Anthony. English for specific purposes: What does it mean? Why is it different?https://www.researchgate.net/publication/267631304.

4. Hoffmann L. Kommunikationsmittel Fachsprache. Eine Einführung. - Tübingen: Gunter Narr Verlag, 1985. - 307 s.

5. Кияк Т.Р., Огуй О.Д., Науменко А.М. Теорія та практика перекладу (німецька мова). - Вінниця: Нова книга, 2006.

$-592 \mathrm{c}$

6. Ящук О., Цепкало О. Стилістичні особливості науковотехнічних текстів у навчанні професійно-орієнтованій англійській мові//Фаховий та художній переклад: теорія, методологія, практика: матеріали IV Міжнародної науково-практичної конференції 1-2 квітня 2011 р. - К., 2011. C. $368-372$.

7. Галушко Т. Поняття комунікативної еквівалентності у фаховому перекладі// Фаховий та художній переклад: теорія, методологія, практика: матеріали IV Міжнародної науково-практичної конференції 1-2 квітня 2011 р. - К., 2011. - C. 45-49.

\section{REFERENCES TRANSLITERATED}

5. Kiyak T., Ohuy O., Naumenko A. Theory and Practice of Translation (German). - Vinnitsya: Nova Kniha, 2006. - 592 p.

Theoretical and Practical Conference 1-2 April 2011. - Kyiv, 2011. - Pp. 368-372.

6. Yaschuk O., Tsepkalo O. Stylistic Specifics of Scientific and Technical Texts in Teaching English for Special Purposes//Translating Fiction and Special Texts: Translation Theory, Methodology and Practice: Materials of the IV International

7. Halushko T. The Notion of Communicative Equivalence in Translating Special Texts// Translating Fiction and Special Texts: Translation Theory, Methodology and Practice: Materials of the IV International Theoretical and Practical Conference 1-2 April 2011. - Kyiv, 2011. - Pp. 45-49. 